\title{
Production of antifungal compounds by Trichoderma spp. to control Phytophthora nicotianae, causal agent of gummosis on citrus
}

\author{
Jaila Ferreira Meloํㅡㄹ Eduardo da Silva Martins² \& Katia Cristina Kupper ${ }^{3}$
}

\section{SUMMARY}

Orange crops in Brazil are affected by various diseases such as gummosis caused by Phytophthora nicotianae, which is controlled by chemical fungicides, by preventive nature through cultural practices and utilization of tolerant rootstock. However, the high costs and environmental problems caused by the intensive use these fungicides have led to the search for alternative methods of control. The objective this study was to evaluate the in vitro antagonistic activity of Trichoderma spp. isolates against $P$. nicotianae by the production of antimicrobial compounds and an alfalfa seedling bioassay, thus, 12 out of the 50 isolates of Trichoderma spp. evaluated were selected based on in vitro screening to compose bioassay treatments. The paired culture showed that all isolates tested inhibited the mycelial growth of the pathogen. In the production of antimicrobial compounds, 41 isolates produced volatile compounds using dextrose as carbon source; however, further assays showed that the use of sucrose or maltose as carbon source increases the production of these compounds. Seven isolates of Trichoderma spp. produced thermostable compounds and 14 isolates produced cell-free antimicrobial compounds of the antagonist. In the alfalfa seedling bioassay, four isolates of Trichoderma spp. inhibited the formation of sporangia and mycelia growth. The in vitro evaluation concerning to the antimicrobial compound production by the Trichoderma spp. isolates and the alfalfa seedling bioassay were able to select biocontrol agents to control P. nicotianae. The four most promising isolates were TB12, TB14, TB28, and TB30 and the mechanisms of action that may be involved in the biocontrol are production of volatile compounds and cell-free filtrates by the antagonists.

Index terms: alfalfa seedling bioassay, Citrus spp., antimicrobial compounds.

\section{Produção de compostos antifúngicos por Trichoderma spp. para controle de Phytophthora nicotianae, agente causal de gomose em citros}

\section{RESUMO}

A cultura da laranja no Brasil é afetada por várias doenças, como a gomose, causada por Phytophtora nicotianae, cujo controle é comumente realizado por aplicações de produtos químicos. Porém, devido aos custos financeiros e problemas ambientais ocasionados pelo uso intensivo destas aplicações, faz-se necessário a busca por métodos alternativos de controle. Este trabalho teve por objetivo avaliar a ação antagônica de isolados de Trichoderma spp. para controle de P. nicotianae, através da produção de compostos antimicrobianos, por meio destes microganimsos, além da

\footnotetext{
${ }^{1}$ Faculdade de Ciências Agrárias e Veterinárias, Universidade Estadual Paulista - UNESP, Jaboticabal, SP, Brazil

${ }^{2}$ Universidade do Estado de Minas Gerais - UEMG, Frutal, MG, Brazil

${ }^{3}$ Centro de Citricultura Sylvio Moreira, Instituto Agronômico de Campinas - IAC, Campinas, SP, Brazil

Corresponding author: Katia Cristina Kupper, Centro de Citricultura Sylvio Moreira, Instituto Agronômico de Campinas - IAC, Rodovia Anhanguera km 158, CP 04, CEP 13490-970, Cordeirópolis, SP, Brazil. E-mail: katia@centrodecitricultura.br
} 
realização de um bioensaio com plântulas de alfafa. Para compor os tratamentos do bioensaio, foram selecionados 12 dos 50 isolados de Trichoderma spp. avaliados in vitro. No cultivo pareado observou-se que todos os isolados inibiram o crescimento micelial do fitopatógeno. Na produção de compostos antimicrobianos, 41 isolados produziram compostos voláteis utilizando como fonte de carbono a dextrose, no entanto, em estudos posteriores, foi verificado que a utilização de sacarose ou maltose, como fontes de carbono, aumentou a produção destes compostos. Sete isolados de Trichoderma produziram compostos termoestáveis e 14 produziram compostos antimicrobianos livres de células do antagônico. No bioensaio com plântulas de alfafa foi observado que quatro isolados de Trichoderma inibiram a formação de esporângios e de micélios do fitopatógeno. Diante dos resultados obtidos, concluiu-se que as avaliações in vitro com relação à produção de compostos antimicrobianos pelos isolados de Trichoderma e o bioensaio com plântulas de alfafa mostraram capacidade para selecionar isolados com potencial para o controle de P. nicotianae. Os quatro isolados mais promissores foram: TB12, TB14, TB28 e TB30 e, os mecanismos de ação que podem estar envolvidos no biocontrole são a produção de compostos voláteis e livres de células pelos antagonistas.

Termos de indexação: bioensaio com plântulas de alfafa, Citrus spp., compostos antimicrobianos.

\section{INTRODUCTION}

Orange is one of the leading exports in Brazil. In the state of São Paulo, the area occupied to citrus growing for the 2013/14 crops was estimated at 501.8 hectares, and the producing area was estimated at 464.4 hectares. The orange production of the 2013/14 crops was around 270 40.8-kg boxes (CONAB, 2014). In addition, Brazil is the world's largest exporter of frozen concentrated orange juice, which, along with other by-products, has generated nearly 1.5 billion dollars in exports per year (FAO, 2014).

Among the various citrus phytosanitary problems, Phytophthora gummosis causes a reduction in productivity which leads to profit reduction. This disease has affected citrus trees world wide and is caused by Phytophthora parasitica, also referred to as $P$. nicotianae (Breda de Haan) (Tucker) var. parasitic (Dastur) Watherhouse. (Graham \& Timmer, 1992).

P. nicotianae is responsible for the greatest damages in nurseries in Brazil although P. citrophthora (Sm. \& Sm) Leonian and other Phytophthora species have already been described as causing this disease. The major damage is stem and root rot, which can hinder the proper development of citrus seedlings in the seed bed or even result in death of the tree if the damage affects the entire trunk circumference (Feichtenberger, 2001).

P. nicotianae is an oomycete that consists of hyaline and non-septate hyphae and hyaline sporangia, which can reproduce both sexually and asexually. It produces structures of resistance, such as oospores, zoospores, and chlamydospores, and, to a lesser degree, sporangia, under favorable environmental conditions. Sporangia can germinate either directly, by the formation of germ tubes, or indirectly, by the formation of zoospores in free water, stimulated by a drop in temperature (Graham \& Menge, 1999).

The disease is controlled by preventive measures that include the use of healthy seedlings and rootstocks or the applications of fungicides such as fosetyl-Al and metalaxyl in the seedlings (Matheron \& Porchas, 2000). However, the high costs and environmental impacts of these chemicals have led to the search for alternative methods of control. As a result, new alternatives for control of this disease have been investigated, especially those that are more compatible to agroecosystems, more economical, and incorporate the fundamental principles of sustainability (Corrêa et al., 2011).

Among the biological control agents, fungal species belonging to the genus Trichoderma spp. have been widely studied as biological control agents against soil-borne pathogens such as Phytophthora spp. In addition to being biocontrol agents, these microorganisms are also plant growth promoters and can induce plant resistance to the pathogens (Saba et al., 2012; Saksirirat et al., 2009).

Currently, more than 250 products based on Trichoderma spp. are manufactured and marketed for use on several crops in the international market and according to Woo et al. (2014), a large distribuition of Trichoderma formulations has been found in all geographical regions worldwide. Some products based on this antagonistic fungus are effective in reducing incidence of root rot and in the severity of diseases caused by soil-borne pathogens, such as Fusarium, Phytophthora, Pythium, Rhizoctonia, Sclerotium, and Sclerotinia. These biological products can be used either for the treatment of substrates as for the treatment of 
seeds, as can be used in spraying onto the aerial parts of the plant (Harman et al., 2004).

Therefore, this study aimed to evaluate the production of antimicrobial compounds by different isolates of Trichoderma spp. and the use of the alfalfa seedling bioassay methodology for the selection of promising isolates of Trichoderma spp. in the biocontrol.

\section{MATERIAL AND METHODS}

\section{Microorganisms}

The following isolates were evaluated: 25 Trichoderma spp. isolates obtained from banana producing regions in the states of São Paulo and Rio de Janeiro, Brazil (TB01, TB02, ТВ03, ТВ04, ТВ06, ТВ07, ТВ08, ТВ09, ТВ1O, TB11, TB12, TB13, TB14, TB16, TB17, TB18, TB21, TB22, ТВ25, ТВ28, TB29, ТВ30, ТВ31, ТВ32, ТВ34); 25 Trichoderma spp. isolates obtained from soybean producing regions in the state of Goiás, Brazil (CE200, CE300, F1A10O11, F1A2T1001, F1A2T1014, F1A2T2, F1A9T2002, F1A9T2006, F2A3T1024, F2A3T1O24, F2A3T18030, F3A3T1010, F3A5T1015, F3A5T1025, F4A5T1, F4A5T1004, F4A5T1005, F4A1T1008, F4A1T1009, F4A4T1022, T1A1029, T1A2F1017, T2T1A2, T2A2F1018, T2A2F1021); and 01 P. nicotianae isolate (IAC-01/95). All of these microorganisms belong to the culture collection of the Plant Pathology and Biological Control Laboratory at the "Sylvio Moreira" Citrus Center/ IAC, Cordeirópolis/SP.

\section{Influence of Trichoderma spp. isolates on the mycelial growth of Phytophthora nicotianae}

The antagonistic effect of Trichoderma spp. on the mycelial growth of the phytopathogen was evaluated using paired culture in Petri dishes containing Potato Dextrose Agar (Dennis \& Webster 1971).

Mycelium discs $(5 \mathrm{~mm})$ cut from the actively growing colony margins of 7-day old P. nicotianae colonies grown on carrot agar medium (CA) were transferred to Petri dishes containing potato dextrose agar (PDA) and placed $3 \mathrm{~cm}$ apart from same size discs of each 7-day old culture of Trichoderma spp isolate. Plates with the pathogen without the presence of the potential antagonists were used as control. The cultures were incubated in a BOD incubator at $27^{\circ} \mathrm{C}$ and $12-\mathrm{h}$ photoperiod. The P. nicotianae colonies were evaluated for mycelial growth by measuring colony diameter in two perpendicular directions on each culture plate after 7 days of incubation. A completely randomized design with five replications was used. Data were subjected to analysis of variance (ANOVA), and means were compared using the Tukey test at 5\% probability level.

\section{Evaluation of antimicrobial compound produced by the isolates of Trichoderma spp.}

\section{Production of volatile compounds}

In order to assess the production of volatile compounds by Trichoderma spp. isolates, the assays were carried out on split plates containing PDA medium to prevent any physical contact between the non-volatile exudates produced by the fungus and $P$. nicotianae in the culture medium. One 5-mm disc of the medium containing Trichoderma spp. isolate was placed one side of the split plate, and one 5-mm disc of the medium containing the pathogen was placed on the other side of plate (the opposite side). The plates were sealed with parafilm and incubated in a BOD chamber at $27^{\circ} \mathrm{C}$ and $12 \mathrm{~h}$ photoperiod. The diameter of the P. nicotianae colonies was evaluated in two perpendicular directions on each culture plate after 7 days of incubation.

\section{Production of thermostable antimicrobial compounds by Trichoderma spp. isolates}

The thermal stability of the antifungal compounds produced by the isolates of Trichoderma spp. was verified according to the method described by Frighetto $\&$ Melo (1995). Three discs of mycelium Trichoderma spp. (7-day old) were transferred to $250 \mathrm{~mL}$ Erlenmeyer flasks containing $50 \mathrm{~mL}$ of PDA. The cultures were then incubated at environmental conditions under agitation at $150 \mathrm{rpm}$ for 120 hours. The broth obtained was filtered through Whatman No.4 filter paper, and an aliquot of $10 \mathrm{~mL}$ was transferred to Erlenmeyer flasks $(250 \mathrm{~mL})$ containing $90 \mathrm{~mL}$ of PDA. The culture media were autoclaved at $120^{\circ} \mathrm{C}$ and $1 \mathrm{ATM}$ pressure for 20 minutes and poured into Petri dishes. After solidification, one disc $(5 \mathrm{~mm})$ of the medium containing actively growing P. nicotianae colonies was placed at the center of each Petri dish containing the medium and the metabolite produced by the antagonist. Plates with the phytopathogen 
without the presence of the fungal metabolites were used as control. The cultures were incubated in a BOD chamber at $27^{\circ} \mathrm{C}$ and $12 \mathrm{~h}$ photoperiod. The $P$. nicotianae colonies were evaluated for mycelial growth by measuring colony diameter in two perpendicular directions on each culture plate after 7 days of incubation.

\section{Production of cell-free antifungal compounds by Trichoderma spp. isolates}

Three discs of mycelium Trichoderma spp. (7-day old) were transferred to $250 \mathrm{~mL}$ Erlenmeyer flasks containing $50 \mathrm{ml}$ of PDA, and the cultures were incubated at environmental conditions under agitation at $150 \mathrm{rpm}$ for 120 hours. An aliquot of $15 \mathrm{~mL}$ of the fermentation broth correspond to each Trichoderma spp. isolate was centrifuged, filtered through Whatman No. 4 filter paper, and then filtered again through a Millipore membrane $(0.45 \mathrm{uM})$ in order to obtain a cell-free filtrate of Trichoderma spp. (Frighetto \& Melo, 1995).

An aliquot of $10 \mathrm{~mL}$ of each filtrate was transferred to $250 \mathrm{~mL}$ Erlenmeyer flasks containing $90 \mathrm{~mL}$ of melted PDA (approximately $70^{\circ} \mathrm{C}$ ). The medium of each treatment was poured into Petri dishes. After solidification, one disc $(5 \mathrm{~mm})$ of the medium containing 7-day old phytopathogen was placed at the center of the dishes. Plates with PDA without the presence of the fungal metabolites were used as control. The cultures were incubated at $27^{\circ} \mathrm{C}$ for seven days, and subsequently the $P$. nicotianae colonies were evaluated for mycelial growth by measuring colony diameter in two perpendicular directions.

\section{Statistical analysis}

A completely randomized design with five replications was used in all assays of antimicrobial compound production by Trichoderma spp.. Data were subjected to analysis of variance (ANOVA), and means were compared using the Tukey test at 5\% probability level.

\section{Effect of carbon sources on the production of volatile compounds}

Based on the results obtained in the previous assays, 12 Trichoderma spp. isolates (TB10, TB12, TB13, TB14, TB21, TB22, TB28, TB30, F1A2T1001, F2T1A1029, F1A9T2006, and T2A2F1021) were inoculated again to produce volatile compounds using PDA culture medium supplemented with different carbon sources: $20 \mathrm{~g} / \mathrm{L}$ glucose, sucrose, or maltose. The production of volatile compounds followed the same method previously described, using split plates. Plates with the phytopathogen without the presence of Trichoderma spp. were used as control. The plates were sealed with parafilm and incubated at $25^{\circ} \mathrm{C} \pm 3^{\circ} \mathrm{C}$ and $12 \mathrm{~h}$ photoperiod. The $P$. nicotianae colonies were evaluated for mycelial growth by measuring colony diameter in two perpendicular directions on each culture plate after 7 days of incubation. A completely randomized design with five replications was used, and the data were subjected to analysis of variance (ANOVA) and means were compared using the Tukey test at 5\% probability level.

\section{Alfalfa seedling bioassay}

The same 12 Trichoderma spp. isolates (TB10, TB12, TB13, TB14, TB21, TB22, TB28, TB30, F1A2T1001, F2T1A1029, F1A9T2006, and T2A2F1021) were evaluated following the method and rating scale introduced by Leoni \& Ghini (2002) in order to identify the most promising isolates for the biocontrol of $P$. nicotianae using alfalfa seedlings. Alfalfa's seeds (Medicago sativa), previously sanitized with sodium hypochlorite $(2 \% \mathrm{v} / \mathrm{v})$, were germinated. After seven days, the seedlings were transferred to 20 -well polyethylene plates ( $5 \mathrm{~mL}$ well volume). In each well, it was added: $2 \mathrm{~mL}$ of sterile distilled water (SDW), one $5 \mathrm{~mm}$ disc of the CA medium containing 7-day old P. nicotianae, and a $5 \mathrm{~mm}$ disc of the BDA medium containing the potential antagonist. Plates with the alfalfa seedlings in SDW only were used as control. The plates were maintained at room temperature and $12 \mathrm{~h}$ photoperiod, and after four days, a $20 \mathrm{~mm}$ piece was cut from the lower end of the radicle, stained with methylene blue, and evaluated under optical (light) microscope.

In this bioassay, in order to determine the antagonist potential of one or more Trichoderma spp. isolates, two rating scales that classify the level of $P$. nicotianae infection in the alfalfa seedlings were used. With regard to the presence of sporangia $(Z)$, the rating scaleranged from 0 to 4 where: $0=$ no sporangia detected; $1=1-5$ sporangia; $2=6-10$ sporangia; $3=11-50$ sporangia; and $4=$ more than 51 sporangia; with regard to the presence of mycelium (M) the rating scale ranged from 0 to 3 where: $0=$ no mycelium; 1 = too little mycelium; 2 = medium amount of mycelium, and $3=$ high amount of mycelium. The bioassay was carried out using a completely randomized design with four replications. Data were subjected to analysis of 
variance (ANOVA), previously and means were compared using the Tukey test at 5\% probability level.

\section{RESULTS}

\section{Influence of Trichoderma spp. isolates on the mycelial growth of Phytophthora nicotianae}

The results show that all 50 Trichoderma spp. isolates tested were able to significantly inhibit $P$. nicotianae colony growth, with inhibition values that ranged from $29 \%$ (F1A9T2002) to $83 \%$ (CE200), when the microorganisms were evaluated using paired culture in Petri dishes containing PDA (Tables 1-5).

\section{Evaluation of antimicrobial compound production by Trichoderma spp. isolates}

\section{Production of volatile compounds}

The results show that 41 out of the 50 isolates tested were able to produce volatile compounds that significantly inhibited $P$. nicotianae colony growth. In the first assay, TB10 was the only isolate able to affect the size of the pathogen colony (Table 1). In the other assays, all isolates produced volatile compounds that affected the development of the pathogen, with inhibition values ranging from $14 \%$ (F2A3T1024) to 65\% (TB28) (Tables 2-5).

\section{Production of antimicrobial thermostable compounds by Trichoderma spp. isolates}

As for the antimicrobial compounds produced by Trichoderma spp. that were resistant to high temperature, it was observed that TB06 (Assay 1); TB21, TB22, TB28, and F1A2T1001 (Assay 2); TB13 and T2A2F1021 (Assay 4) were the only isolates able to inhibit Phytophthora colony growth, with inhibition values that ranged from $10 \%$ (F1A2T1001) to $48 \%$ (TB06). All other isolates tested did not produce thermostable compounds in sufficient quantities to affect the development of the pathogen (Tables 1-5).

\section{Production of cell-free antifungal compounds by Trichoderma spp. isolates}

The analysis of the production of cell-free culture filtrates of Trichoderma spp. showed that the following isolates produced antimicrobial compounds in sufficient quantities to inhibit pathogen colony growth: TB02, TB04, TB06, TB08, TB09, and TB010 (Assay 1, Table 1); TB21,

Table 1. Mean colony diameters of Phytophthora nicotianae after being paired with different Trichoderma spp. isolates or under the influence of antimicrobial compounds produced by the fungi. Assay 1

\begin{tabular}{|c|c|c|c|c|c|c|c|c|}
\hline \multicolumn{9}{|c|}{ Antimicrobial Compounds } \\
\hline \multirow[b]{2}{*}{ Isolates } & \multicolumn{2}{|c|}{ Paired } & \multicolumn{2}{|c|}{ Volatile } & \multicolumn{2}{|c|}{ Thermostable } & \multicolumn{2}{|c|}{ Cell-free culture } \\
\hline & $\begin{array}{l}\text { diameter } \\
(\mathrm{cm})\end{array}$ & $\begin{array}{c}\text { Inhibition } \\
(\%)\end{array}$ & $\begin{array}{l}\text { diameter } \\
(\mathrm{cm})\end{array}$ & $\begin{array}{c}\text { Inhibition } \\
(\%)\end{array}$ & $\begin{array}{l}\text { diameter } \\
(\mathrm{cm})\end{array}$ & $\begin{array}{c}\text { Inhibition } \\
(\%)\end{array}$ & $\begin{array}{l}\text { diameter } \\
(\mathrm{cm})\end{array}$ & $\begin{array}{c}\text { Inhibition } \\
(\%)\end{array}$ \\
\hline Controls & $5.65 \mathrm{a}^{(1)}$ & - & $4.93 \mathrm{a}$ & - & $3.95 \mathrm{a}$ & - & $3.90 \mathrm{a}$ & - \\
\hline TB01 & $3.58 \mathrm{bc}$ & 36 & $4.90 \mathrm{a}$ & 0.6 & $3.69 \mathrm{ab}$ & 6 & $3.67 \mathrm{a}$ & 6 \\
\hline TB02 & $3.15 \mathrm{bc}$ & 44 & $4.55 \mathrm{ab}$ & 8 & $2.72 \mathrm{ab}$ & 31 & $2.40 \mathrm{c}$ & 38 \\
\hline TB03 & $3.30 \mathrm{bc}$ & 41 & $4.94 \mathrm{a}$ & -0.2 & $3.92 \mathrm{ab}$ & 0.8 & $3.93 \mathrm{a}$ & -0.8 \\
\hline TB04 & $3.85 \mathrm{bc}$ & 32 & $4.58 \mathrm{ab}$ & 7 & $2.86 \mathrm{ab}$ & 27 & $3.06 \mathrm{~b}$ & 21 \\
\hline TB06 & $3.64 \mathrm{bc}$ & 36 & $4.55 \mathrm{ab}$ & 8 & $2.05 \mathrm{~b}$ & 48 & $2.65 \mathrm{bc}$ & 32 \\
\hline TB07 & $3.94 \mathrm{~b}$ & 36 & $4.62 \mathrm{ab}$ & 6 & $3.77 \mathrm{ab}$ & 4 & $3.66 \mathrm{a}$ & 6 \\
\hline TB08 & $3.85 \mathrm{bc}$ & 32 & $4.76 \mathrm{ab}$ & 3 & $2.64 \mathrm{ab}$ & 33 & $2.14 \mathrm{c}$ & 45 \\
\hline TB09 & $3.07 \mathrm{c}$ & 46 & $4.33 \mathrm{ab}$ & 12 & $2.30 \mathrm{ab}$ & 42 & $2.60 \mathrm{bc}$ & 33 \\
\hline TB10 & $3.38 \mathrm{bc}$ & 40 & $4.20 \mathrm{~b}$ & 15 & $3.15 \mathrm{ab}$ & 20 & $2.40 \mathrm{c}$ & 38 \\
\hline TB11 & $3.49 \mathrm{bc}$ & 38 & $4.73 \mathrm{ab}$ & 4 & $3.30 \mathrm{ab}$ & 16 & $3,98 \mathrm{a}$ & -2 \\
\hline CV \% & 10.08 & - & 6.41 & - & 28.10 & - & 8.88 & - \\
\hline
\end{tabular}

${ }^{(1)}$ Means followed by the same lower case letters within a column are not significantly different at $5 \%$ probability level by the Tukey test. 
Table 2. Mean colony diameters of Phytophthora nicotianae after being paired with different Trichoderma spp. isolates under the influence of antimicrobial compounds produced by the fungi. Assay 2

\begin{tabular}{|c|c|c|c|c|c|c|c|c|}
\hline \multicolumn{9}{|c|}{ Antimicrobial Compounds } \\
\hline \multirow[b]{2}{*}{ Isolates } & \multicolumn{2}{|c|}{ Paired } & \multicolumn{2}{|c|}{ Volatile } & \multicolumn{2}{|c|}{ Thermostable } & \multicolumn{2}{|c|}{ Cell-free culture } \\
\hline & $\begin{array}{l}\text { diameter } \\
(\mathrm{cm})\end{array}$ & $\begin{array}{c}\text { Inhibition } \\
(\%)\end{array}$ & $\begin{array}{l}\text { diameter } \\
(\mathrm{cm})\end{array}$ & $\begin{array}{c}\text { Inhibition } \\
(\%)\end{array}$ & $\begin{array}{l}\text { diameter } \\
(\mathrm{cm})\end{array}$ & $\begin{array}{c}\text { Inhibition } \\
(\%)\end{array}$ & $\begin{array}{l}\text { diameter } \\
(\mathrm{cm})\end{array}$ & $\begin{array}{c}\text { Inhibition } \\
(\%)\end{array}$ \\
\hline Controls & $6.96 \mathrm{a}^{(1)}$ & - & $7.15 \mathrm{a}$ & - & $3.92 \mathrm{ab}$ & - & $3.79 \mathrm{a}$ & - \\
\hline TB18 & $3.69 \mathrm{~b}$ & 47 & $3.12 \mathrm{~b}$ & 56 & $3.75 \mathrm{abc}$ & 4 & $3.72 \mathrm{a}$ & 2 \\
\hline TB21 & $2.88 \mathrm{bc}$ & 59 & $2.98 \mathrm{~b}$ & 58 & $2.08 \mathrm{e}$ & 47 & $1.47 \mathrm{c}$ & 61 \\
\hline TB22 & $1.73 \mathrm{c}$ & 75 & $3.19 \mathrm{~b}$ & 55 & $3.47 \mathrm{~cd}$ & 11 & $2.79 \mathrm{~b}$ & 26 \\
\hline TB25 & $2.54 \mathrm{bc}$ & 63 & $2.96 \mathrm{~b}$ & 59 & $3.94 \mathrm{ab}$ & -0.5 & $3.62 \mathrm{a}$ & 4 \\
\hline TB28 & $2.38 \mathrm{bc}$ & 66 & $2.52 \mathrm{~b}$ & 65 & $3.26 \mathrm{~d}$ & 17 & $1.91 \mathrm{c}$ & 50 \\
\hline TB32 & $3.03 \mathrm{bc}$ & 56 & $3.29 \mathrm{~b}$ & 54 & $4.12 \mathrm{a}$ & -5 & $4.03 \mathrm{a}$ & -6.3 \\
\hline F1A2T1001 & $2.05 \mathrm{bc}$ & 70 & $3.86 \mathrm{~b}$ & 46 & $3.52 \mathrm{~cd}$ & 10 & $3.64 \mathrm{a}$ & 4 \\
\hline F1A2T1014 & $2.00 \mathrm{bc}$ & 71 & $2.84 \mathrm{~b}$ & 60 & $3.60 \mathrm{bcd}$ & 8 & $3.92 \mathrm{a}$ & -3.4 \\
\hline CE200 & $1.20 \mathrm{c}$ & 83 & $3.00 \mathrm{~b}$ & 58 & $3.98 \mathrm{ab}$ & -1.5 & $3.74 \mathrm{a}$ & 1 \\
\hline CE300 & $1.40 \mathrm{c}$ & 80 & $3.06 \mathrm{~b}$ & 57 & $4.00 \mathrm{a}$ & -2 & $3.71 \mathrm{a}$ & 2 \\
\hline $\mathrm{CV} \%$ & 32.32 & - & 21.86 & - & 5.15 & - & 8.08 & - \\
\hline
\end{tabular}

${ }^{(1)}$ Means followed by the same lower case letters within a column are not significantly different at $5 \%$ probability level by the Tukey test.

Table 3. Mean colony diameters of Phytophthora nicotianae after being paired with different Trichoderma spp. isolates under the influence of antimicrobial compounds produced by the fungi. Assay 3

\begin{tabular}{|c|c|c|c|c|c|c|c|c|}
\hline \multicolumn{9}{|c|}{ Antimicrobial Compounds } \\
\hline \multirow[b]{2}{*}{ Isolates } & \multicolumn{2}{|c|}{ Paired } & \multicolumn{2}{|c|}{ Volatile } & \multicolumn{2}{|c|}{ Thermostable } & \multicolumn{2}{|c|}{ Cell-free culture } \\
\hline & $\begin{array}{l}\text { diameter } \\
(\mathrm{cm})\end{array}$ & $\begin{array}{c}\text { Inhibition } \\
(\%)\end{array}$ & $\begin{array}{l}\text { diameter } \\
(\mathrm{cm})\end{array}$ & $\begin{array}{c}\text { Inhibition } \\
(\%)\end{array}$ & $\begin{array}{l}\text { diameter } \\
(\mathrm{cm})\end{array}$ & $\begin{array}{c}\text { Inhibition } \\
(\%)\end{array}$ & $\begin{array}{l}\text { diameter } \\
(\mathrm{cm})\end{array}$ & $\begin{array}{c}\text { Inhibition } \\
(\%)\end{array}$ \\
\hline Controls & $6.85 \mathrm{a}^{(1)}$ & - & $7.25 \mathrm{a}$ & - & $4.29 \mathrm{abc}$ & - & $4.20 \mathrm{bc}$ & - \\
\hline TB29 & $2.25 \mathrm{bc}$ & 67 & $2.88 \mathrm{c}$ & 60 & $3.57 \mathrm{abc}$ & 17 & $4.06 \mathrm{bc}$ & 3 \\
\hline TB30 & $2.41 \mathrm{bc}$ & 65 & $2.97 \mathrm{c}$ & 59 & $3.94 \mathrm{abc}$ & 8 & $1.90 \mathrm{e}$ & 55 \\
\hline F1A2T2013 & $3.64 \mathrm{~b}$ & 47 & $4.62 \mathrm{~b}$ & 36 & $3.80 \mathrm{abc}$ & 11 & $5.06 \mathrm{ab}$ & -20.5 \\
\hline F1A9T2006 & $2.05 \mathrm{c}$ & 70 & $3.11 \mathrm{c}$ & 57 & $3.15 \mathrm{bc}$ & 27 & $2.03 \mathrm{e}$ & 52 \\
\hline F2A3T1830 & $3.67 \mathrm{~b}$ & 46 & $3.20 \mathrm{c}$ & 56 & $4.77 \mathrm{a}$ & -11 & $4.15 \mathrm{bc}$ & 1 \\
\hline F2T1A1029 & $3.20 \mathrm{bc}$ & 53 & $2.50 \mathrm{c}$ & 65 & $4.70 \mathrm{a}$ & -10 & $2.90 \mathrm{de}$ & 31 \\
\hline F3A5T1015 & $2.83 \mathrm{bc}$ & 59 & $3.30 \mathrm{bc}$ & 54 & $4.15 \mathrm{abc}$ & 3 & $3.70 \mathrm{~cd}$ & 12 \\
\hline F3A5T1025 & $2.34 \mathrm{bc}$ & 66 & $2.90 \mathrm{c}$ & 60 & $3.78 \mathrm{abc}$ & 12 & $4.70 \mathrm{abc}$ & -12 \\
\hline F4A5T1003 & $3.30 \mathrm{bc}$ & 52 & $3.49 \mathrm{bc}$ & 52 & $2.82 \mathrm{c}$ & 34 & $5.50 \mathrm{a}$ & -31 \\
\hline F4A4T1022 & $3.25 \mathrm{bc}$ & 52 & $2.80 \mathrm{c}$ & 61 & $4.40 \mathrm{ab}$ & -2.6 & $4.20 \mathrm{bc}$ & 0 \\
\hline $\mathrm{CV} \%$ & 22.75 & - & 17.80 & - & 18.06 & - & 13.13 & - \\
\hline
\end{tabular}

${ }^{(1)}$ Means followed by the same lower case letters within a column are not significantly different at $5 \%$ probability level by the Tukey test. 
Table 4. Mean colony diameters of Phytophthora nicotianae after being paired with different Trichoderma spp. isolates under the influence of antimicrobial compounds produced by the fungi. Assay 4

\begin{tabular}{|c|c|c|c|c|c|c|c|c|}
\hline \multicolumn{9}{|c|}{ Antimicrobial Compounds } \\
\hline \multirow[b]{2}{*}{ Isolates } & \multicolumn{2}{|c|}{ Paired } & \multicolumn{2}{|c|}{ Volatile } & \multicolumn{2}{|c|}{ Thermostable } & \multicolumn{2}{|c|}{ Cell-free culture } \\
\hline & $\begin{array}{l}\text { diameter } \\
(\mathrm{cm})\end{array}$ & $\begin{array}{c}\text { Inhibition } \\
(\%)\end{array}$ & $\begin{array}{l}\text { diameter } \\
(\mathrm{cm})\end{array}$ & $\begin{array}{c}\text { Inhibition } \\
(\%)\end{array}$ & $\begin{array}{l}\text { diameter } \\
(\mathrm{cm})\end{array}$ & $\begin{array}{c}\text { Inhibition } \\
(\%)\end{array}$ & $\begin{array}{l}\text { diameter } \\
(\mathrm{cm})\end{array}$ & $\begin{array}{c}\text { Inhibition } \\
(\%)\end{array}$ \\
\hline Controls & $6.00 \mathrm{a}^{(1)}$ & - & $7.08 \mathrm{a}$ & - & $3.95 \mathrm{bc}$ & - & $3.69 \mathrm{abc}$ & - \\
\hline TB12 & $4.10 \mathrm{~b}$ & 32 & $3.15 \mathrm{bc}$ & 55 & $3.92 \mathrm{~cd}$ & 0.8 & $2.13 \mathrm{~d}$ & 42 \\
\hline TB13 & $2.45 \mathrm{~d}$ & 59 & $3.33 \mathrm{bc}$ & 53 & $3.45 \mathrm{de}$ & 13 & $2.45 \mathrm{~cd}$ & 34 \\
\hline TB14 & $2.70 \mathrm{~d}$ & 55 & $3.75 \mathrm{~b}$ & 47 & $4.05 \mathrm{bc}$ & -2.5 & $1.80 \mathrm{~d}$ & 51 \\
\hline TB16 & $3.00 \mathrm{~cd}$ & 50 & $2.72 \mathrm{c}$ & 62 & $3.97 \mathrm{bc}$ & -0.5 & $4.12 \mathrm{a}$ & -12 \\
\hline F3A3T1010 & $3.90 \mathrm{bc}$ & 35 & $3.27 \mathrm{bc}$ & 54 & $4.43 \mathrm{ab}$ & -12 & $4.05 \mathrm{ab}$ & -10 \\
\hline F4A1T1009 & $2.95 \mathrm{~cd}$ & 51 & $3.67 \mathrm{bc}$ & 48 & $4.79 \mathrm{a}$ & -21 & $4.80 \mathrm{a}$ & -30 \\
\hline F4A5T1005 & $2.75 \mathrm{~d}$ & 54 & $3.18 \mathrm{bc}$ & 55 & $4.06 \mathrm{bc}$ & -3 & $4.86 \mathrm{a}$ & -32 \\
\hline T1A1029 & $3.85 \mathrm{bc}$ & 36 & $3.28 \mathrm{bc}$ & 54 & $4.05 \mathrm{bc}$ & -2.5 & $4.69 \mathrm{a}$ & -27 \\
\hline T2A2F1021 & $3.25 \mathrm{bcd}$ & 46 & $3.13 \mathrm{bc}$ & 56 & $3.22 \mathrm{e}$ & 18 & $4.58 \mathrm{a}$ & -24 \\
\hline TK2002 & $3.30 \mathrm{bcd}$ & 45 & $3.99 \mathrm{~b}$ & 44 & $3.84 \mathrm{~cd}$ & 3 & $2.69 \mathrm{bcd}$ & 27 \\
\hline $\mathrm{CV} \%$ & 12.95 & - & 12.33 & - & 5.66 & - & 18.28 & - \\
\hline
\end{tabular}

${ }^{(1)}$ Means followed by the same lower case letters within a column are not significantly different at $5 \%$ probability level by the Tukey test.

Table 5. Mean colony diameters of Phytophthora nicotianae after being paired with different Trichoderma spp. isolates under the influence of antimicrobial compounds produced by the fungi. Assay 5

\begin{tabular}{|c|c|c|c|c|c|c|c|c|}
\hline \multicolumn{9}{|c|}{ Antimicrobial Compounds } \\
\hline \multirow[b]{2}{*}{ Isolates } & \multicolumn{2}{|c|}{ Paired } & \multicolumn{2}{|c|}{ Volatile } & \multicolumn{2}{|c|}{ Thermostable } & \multicolumn{2}{|c|}{ Cell-free culture } \\
\hline & $\begin{array}{l}\text { diameter } \\
(\mathrm{cm})\end{array}$ & $\begin{array}{c}\text { Inhibition } \\
(\%)\end{array}$ & $\begin{array}{l}\text { diameter } \\
(\mathrm{cm})\end{array}$ & $\begin{array}{c}\text { Inhibition } \\
(\%)\end{array}$ & $\begin{array}{l}\text { diameter } \\
(\mathrm{cm})\end{array}$ & $\begin{array}{c}\text { Inhibition } \\
(\%)\end{array}$ & $\begin{array}{l}\text { diameter } \\
(\mathrm{cm})\end{array}$ & $\begin{array}{c}\text { Inhibition } \\
(\%)\end{array}$ \\
\hline Control & $4.48 \mathrm{a}^{(1)}$ & - & $6.00 \mathrm{a}$ & - & $3.78 \mathrm{abc}$ & - & $4.09 \mathrm{a}$ & - \\
\hline TB17 & $2.53 \mathrm{def}$ & 44 & $4.75 \mathrm{bcd}$ & 21 & $3.71 \mathrm{abc}$ & 2 & $3.87 \mathrm{a}$ & 5 \\
\hline TB31 & 2.73 cde & 39 & $5.00 \mathrm{bc}$ & 17 & $3.65 \mathrm{bc}$ & 3 & $2.92 \mathrm{a}$ & 29 \\
\hline TB34 & $2.97 \mathrm{~cd}$ & 34 & $4.85 \mathrm{bcd}$ & 19 & $4.01 \mathrm{abc}$ & -6 & $4.01 \mathrm{a}$ & 2 \\
\hline F1A1011 & $2.18 \mathrm{efg}$ & 51 & 4.30 cde & 28 & $3.48 \mathrm{c}$ & 8 & $3.42 \mathrm{a}$ & 16 \\
\hline F1A9T2002 & $3.16 \mathrm{bc}$ & 29 & $4.90 \mathrm{bc}$ & 18 & $4.20 \mathrm{a}$ & -11 & $3.30 \mathrm{a}$ & 19 \\
\hline F2A3T1024 & $3.16 \mathrm{bc}$ & 29 & $5.15 \mathrm{~b}$ & 14 & $4.25 \mathrm{a}$ & -12 & $3.85 \mathrm{a}$ & 6 \\
\hline F4A1T1008 & $2.75 \mathrm{~cd}$ & 39 & $4.80 \mathrm{bcd}$ & 20 & $4.23 \mathrm{a}$ & -12 & $4.14 \mathrm{a}$ & -1.2 \\
\hline T1A2F1017 & $1.95 \mathrm{~g}$ & 56 & $4.15 \mathrm{de}$ & 31 & $4.15 \mathrm{ab}$ & -10 & $4.10 \mathrm{a}$ & -0.2 \\
\hline T2A2F1018 & 2.68 cde & 40 & $3.65 \mathrm{ef}$ & 39 & $3.91 \mathrm{abc}$ & -3 & $3.42 \mathrm{a}$ & 16 \\
\hline T2T1A2016 & $2.05 \mathrm{fg}$ & 54 & $3.20 \mathrm{f}$ & 47 & $3.91 \mathrm{abc}$ & -3 & $3.16 \mathrm{a}$ & 23 \\
\hline $\mathrm{CV} \%$ & 9.25 & - & 7.23 & - & 6.49 & - & 21.17 & - \\
\hline
\end{tabular}

${ }^{(1)}$ Means followed by the same lower case letters within a column are not significantly different at $5 \%$ probability level by the Tukey test. 
TB22, and TB28 (Assay 2, Table 2); TB30, F1A9T2006, and F2T1A1029 (Assay 3, Table 3); TB12 and TB14 (Assay 4, Table 4). None of the isolates tested in assay 5 (Table 5) produced cell-free antifungal compounds in sufficient quantities to affect the Phytophthora mycelial development.

\section{Effect of carbon sources on the production of volatile compounds}

The analysis of the effect of different carbon sources that were used to supplement the PDA culture medium to test the production of volatiles by Trichoderma spp. isolates showed that compound production depended not only on the isolate of the antagonist, but also on the

Table 6. Effect of different carbon sources on the production of volatile compounds by Trichoderma spp. and on Phytophthora nicotianae colony growth

\begin{tabular}{cc}
\hline Carbon Sources & Mean colony diameter $(\mathrm{cm})$ \\
\hline Sucrose & $2.78 \mathrm{~b}^{(1)}$ \\
Maltose & $2.86 \mathrm{~b}$ \\
Glucose & $3.32 \mathrm{a}$ \\
\hline
\end{tabular}

(1) Means followed by the same lower case letters within a column are not significantly different at $5 \%$ probability level by the Tukey test. carbon source used. Sucrose and maltose favored the production of these volatiles (Table 6), and although all isolates tested produced volatile compounds in sufficient quantities to inhibit the pathogen colony growth, the inhibition values of the Phytophthora colony ranged from $30 \%$ (F1A2T1001) to 54\% (TB010) (Table 7).

\section{Alfalfa seedling bioassay}

The data of alfalfa seedling bioassay showed that the isolates TB10, TB12, TB14, TB21, TB28, TB30, and F1A9T2006 inhibited the production of $P$. nicotianae sporangia. With respect to the amount of mycelia, TB12, TB14, TB28, and TB30 were the only isolates that significantly inhibited mycelial growth (Table 8). Moreover, it was found that these last ones were able to affect both sporangia and mycelium production, and therefore they are considered as promising biological control agents against $P$. nicotianae by the infestation of alfalfa seedlings' method.

\section{DISCUSSION}

The high incidence of gummosis, disease caused by $P$. nicotianae, results in significant economic losses to the Brazilian citrus industry. Therefore, new methods of

Table 7. Mean colony diameter of Phytophthora nicotianae under the influence of volatile compounds produced by Trichoderma spp. grown on PDA medium supplemented with different carbon sources

\begin{tabular}{|c|c|c|c|}
\hline \multirow{2}{*}{ Isolates } & Sucrose & Maltose & Glucose \\
\hline & \multicolumn{3}{|c|}{ Mean colony diameter of Phytophthora nicotianae $(\mathrm{cm})$} \\
\hline Control & $3.85 \mathrm{a}^{(1)}$ & $5.25 \mathrm{a}$ & $5.18 \mathrm{a}$ \\
\hline TB10 & $2.25 \mathrm{~cd}$ & $2.38 \mathrm{~b}$ & $2.31 \mathrm{c}$ \\
\hline TB12 & $2.62 \mathrm{bcd}$ & $2.60 \mathrm{~b}$ & $3.20 \mathrm{bc}$ \\
\hline TB13 & $2.67 \mathrm{bcd}$ & $3.07 \mathrm{~b}$ & $3.25 \mathrm{bc}$ \\
\hline TB14 & $2.99 \mathrm{bc}$ & $3.07 \mathrm{~b}$ & $2.90 \mathrm{c}$ \\
\hline TB21 & $2.68 \mathrm{bcd}$ & $2.75 \mathrm{~b}$ & $2.52 \mathrm{c}$ \\
\hline TB22 & $3.30 \mathrm{ab}$ & $2.62 \mathrm{~b}$ & $3.16 \mathrm{bc}$ \\
\hline TB28 & $2.60 \mathrm{bcd}$ & $2.38 \mathrm{~b}$ & $3.08 \mathrm{bc}$ \\
\hline TB30 & $2.15 \mathrm{~d}$ & $2.84 \mathrm{~b}$ & $3.24 \mathrm{bc}$ \\
\hline F1A2T1001 & $3.00 \mathrm{bc}$ & $2.56 \mathrm{~b}$ & $4.38 \mathrm{ab}$ \\
\hline F2T1A1029 & $2.82 \mathrm{bcd}$ & $3.25 \mathrm{~b}$ & $4.38 \mathrm{ab}$ \\
\hline F1A9T2006 & $2.70 \mathrm{bcd}$ & $2.80 \mathrm{~b}$ & $3.56 \mathrm{bc}$ \\
\hline $\mathrm{T} 2 \mathrm{~A} 2 \mathrm{~F} 1021$ & $2.56 \mathrm{bcd}$ & $2.45 \mathrm{~b}$ & $2.50 \mathrm{c}$ \\
\hline $\mathrm{CV} \%$ & 13.14 & 16.98 & 20.25 \\
\hline
\end{tabular}

${ }^{(1)}$ Means followed by the same lower case letters within a column are not significantly different at $5 \%$ probability level by the Tukey test. 
Table 8. Selection of Trichoderma spp. isolates in terms of antagonistic activity against Phytophthora nicotianae using the infestation of alfalfa seedlings' method

\begin{tabular}{ccc}
\hline \multirow{2}{*}{ Treatments } & \multicolumn{2}{c}{ Level of infestation with P. nicotianae in alfalfa seedlings } \\
\cline { 2 - 3 } & presence of sporangia & presence of mycelium \\
\hline Non-inoculated Control & $0.71 \mathrm{~b}^{(\mathrm{Z})}$ & $0.71 \mathrm{~b}^{(\mathrm{M})}$ \\
Inoculated Control & $1.56 \mathrm{a}$ & $1.48 \mathrm{a}$ \\
TB10 & $0.71 \mathrm{~b}$ & $0.84 \mathrm{ab}$ \\
TB12 & $0.71 \mathrm{~b}$ & $0.71 \mathrm{~b}$ \\
TB13 & $0.88 \mathrm{ab}$ & $0.97 \mathrm{ab}$ \\
TB14 & $0.71 \mathrm{~b}$ & $0.71 \mathrm{~b}$ \\
TB21 & $0.71 \mathrm{~b}$ & $0.84 \mathrm{ab}$ \\
TB22 & $1.39 \mathrm{ab}$ & $1.22 \mathrm{ab}$ \\
TB28 & $0.71 \mathrm{~b}$ & $0.71 \mathrm{~b}$ \\
TB30 & $0.71 \mathrm{~b}$ & $0.71 \mathrm{~b}$ \\
F1A2T1001 & $1.05 \mathrm{ab}$ & $0.97 \mathrm{ab}$ \\
F2T1A1029 & $0.88 \mathrm{ab}$ & $0.84 \mathrm{ab}$ \\
F1A9T2006 & $0.71 \mathrm{~b}$ & $0.84 \mathrm{ab}$ \\
T2A2F1021 & $1.22 \mathrm{ab}$ & $0.97 \mathrm{ab}$ \\
\hline
\end{tabular}

(Z)Mean rating of the number of sporangia formed per alfalfa plant. Rating scale for number of sporangia: $0=$ no sporangia detected; $1=1-5$ sporangia; $2=6-10$ sporangia; $3=11-50$ sporangia; and $4=$ more than 51 sporangia. (M) ean rating of the amount of mycelium per alfalfa plant. Rating scale for amount of mycelium: 0 = no mycelium; $1=$ too little mycelium; 2 = medium amount of mycelium, and $3=$ too much mycelium. Means followed by the same lower case letters within a column are not significantly different at $5 \%$ probability by the Tukey test.

controlling this disease are necessary; biological control has become an important alternative to the use of fungicides.

This study aimed to evaluate the in vitro antagonistic activity of different Trichoderma spp. isolates against P. nicotianae by the production of antimicrobial compounds and by an alfalfa seedling bioassay for the selection of the most promising biocontrol isolates. The results show that all 50 Trichoderma spp. isolates tested were able to reduce the development of $P$. nicotianae using paired culture. Corrêa et al. (2011) used the same antagonistic technique and found that the reduction of $P$. parasitica colony growth, in the presence of Trichoderma spp., could be attributed to the release of toxic compounds and nutrient depletion in the culture medium. According to Howell (2003), several Trichoderma species have the ability to produce toxic substances that are able to inhibit the growth of pathogens.

The evaluation of the production of antimicrobial compounds by Trichoderma that could affect the development of $P$. nicotianae in citrus plants showed that 41 Trichoderma spp. isolates produced volatile compounds capable of inhibiting the pathogen colony growth.
Isaias et al. (2014) found that only volatile compounds produced by $T$. harzianum, $T$. koningiopsis, and T. asperellum inhibited the growth of Sclerotium rolfsii and Verticillium dahliae colonies, with values significantly higher than $60 \%$ and between $40 \%$ and $60 \%$, respectively. Martins-Corder \& Melo (1998) found that 4 out of 7 Trichoderma spp. isolates produced volatile compounds with higher inhibitory effect on the growth of $V$. dahliae colony although there were no statistical differences between them. Fialho et al. (2010) studied the biological control of the Phyllosticta citricarpa using the yeast Saccharomyces cerevisiae and related plant pathogen control up to $87.2 \%$ by production of volatile compounds, according to these authors this was attributed to the production of eight substances, mainly alcohols.

However, based on the results obtained in the present study, it can be said that not only the isolates, but also the carbon source used in the Trichoderma spp. culture medium can favor the production of these volatile compounds, which, in this study, was favored by the addition of sucrose or maltose in the culture medium. According to Ezra \& Strobel (2003) the composition of the medium used to 
support the growth of Muscodor albus, which inhibits and kills fungi and bacteria by emitting volatile organic compounds, greatly influences the quality and effectiveness of the volatiles emitted. To the authors, a sucrose enriched medium mostly yielded methyl isobutylketone and acetic acid, butyl ester as the primary volatiles and neither of these substances appeared in any other medium tested.

On the other hand, Rossi-Rodrigues et al. (2009), investigating the growth of four species of Trichoderma in media supplemented with sucrose and glucose, found that the growth rate in the media with glucose was five times higher than that in the media with sucrose and that the growth of T. hamatum was $40 \%$ higher with glucose than with sucrose.

The thermostable compound production analysis showed that only 7 out of the 50 isolates tested (TB06, TB21, TB22, TB28, F1A2T1001, TB13, and T2A2F1021) inhibited the mycelial growth of $P$. nicotianae, showing that even at high temperatures these isolates were capable to release metabolites that inhibited the development of the pathogen. The same was found by Isaias et al. (2014) when studying the production of thermostable nonvolatile metabolites by the 20 Trichoderma spp. isolates against $S$. rolfisii and $V$. dahlia growth; they observed that 4 isolates inhibited the growth of these pathogens, with inhibition values higher than 50\% and from 54\% to $60 \%$, respectively.

The effect of cell-free antifungal compounds produced by Trichoderma spp. showed that 14 Trichoderma spp. isolates (TB02, TB04, TB06, TB08, TB09, TB10, TB12, TB14, TB21, TB22, ТВ28, TB30, F1A9T2006, and F2T1A1029) showed significant inhibition of $P$. nicotianae colony growth. It is assumed that the metabolites produced by most isolates were protein in nature, since, with the exception of TB06, TB21, TB22 and TB28 isolate, no other antifungal substances produced were able to withstand the high temperature. Corrigir: According to Monte (2001), the most of the enzymes tested as purified proteins have presented strong antifungal activity against fungi and that Trichoderma strains have shown great potential in agriculture as active components in fungicidal formulations. Studying the effect of cell-free extracts of Trichoderama spp. on the mycelial growth of Rhizopus stolonifer, Bomfim et al. (2010) found that 4 isolates inhibited the pathogen mycelial growth, exhibiting a remarkable antifungal activity.

It is important to mention that TB06, TB21, TB22 and TB28 produce metabolites that affect the $P$. nicotianae colonies development and, these substances maintained their antagonistic activities even after exposure to high temperature. On the other hand, the Trichoderma isolates F1A2T1001, TB13, and T2A2F1021 only produced antifungal compounds when subjected to autoclaving. A hypothesis is that components present in the microrganisms with activity against to $P$. nicotianae were released to the medium after exposure to high temperatures, according to Kupper \& Fernandes (2002).

In the alfalfa seedling bioassay, which aimed to select the Trichoderma spp. isolates with the best biocontrol potential, it was observed that the isolates TB12, TB14, TB28, and TB30 significantly inhibited the formation of sporangia and mycelium and were thus considered as promising biological control agents against $P$. nicotianae. Moereover, Leoni \& Ghini (2002), who evaluated the antagonistic potential of different bacteria, actinomycetes, and fungi isolates against $P$. nicotianae, reported that only 2 isolates, F9.1 (Aspergillus sp.) and A12.1 (actinomycete, not identified), were considered promising biocontrol agents and that one Trichoderma spp. isolate (F12.3) inhibited the formation of sporangia only at the root of the seedlings.

The present study also indicates that the in vitro antagonistic interactions among the microrganisms do not necessarily lead to the reduction in the number of phytopathogen propagules and consequently to the suppression of the disease. However, the data presented here suggest that the Trichoderma isolates TB12, TB14, TB28, and TB30 are promising biocontrol agents against $P$. nicotianae and that among the mechanisms of action that may be involved in the biocontrol are the production of volatile compounds and cell-free filtrates. These results are partly in agreement with the in vitro results reported by Corrêa et al. (2011). According to these authors, T. pseudokoningii and T. virens were the main growth inhibitors of $P$. parasitica, and the mechanisms responsible for controlling the disease in Rangpur lime plants were, probably, the competition for nutrients and antimicrobial compound production. Malajczuk (1983) also reported that the main mechanisms involved in the biocontrol against Phytophthora spp. can be nutrient competition and antibiosis.

As a conclusion of this work we can say that four out of the 50 Trichoderma spp. isolates evaluated, TB12, TB14, TB28, and TB30 exhibited potential for use as biological control agents, both in vitro (by production antimicrobial compounds) and in the alfalfa seedling bioassay against $P$. nicotianae since these isolates were able to affect the production of sporangia and mycelia. However, further studies on citrus plants are necessary to confirm the potential of these isolates as biocontrol 
agents against the disease. The mechanisms of action that may be involved in the biocontrol are production of volatile compounds and cell-free filtrates by the antagonist. Interactions among plant, pathogen, and fungal antagonist in different environmental conditions and the knowledge about the survival of these Trichoderma isolates in the soil are important factors to be addressed in future studies.

\section{REFERENCES}

Bomfim MP, São José AR, Rebouças TNH, Almeida SS, Souza IBB \& Dias NO (2010) Avaliação antagônica in vitro e in vivo de Trichoderma spp. a Rhizopus stolonifer em maracujazeiro amarelo. Summa Phytopathologica 36: 61-67.

CONAB - Companhia Nacional de Abastecimento (2014). Título. Available from: <http://www.conab.gov. br/OlalaCMS/uploads/arquivos/13_12_12_09_53_25bo letim de_laranja.pdf $>$. Acesssed: $2 \overline{0}$ Out. $\overline{201} \overline{6}$.

Corrêa EB, Kupper KC \& Goes A (2011) Controle biológico da podridão radicular em plantas de limão cravo. Citrus Research \& Technology 32: 127-132.

Dennis C \& Webster J (1971) Antagonistic properties of species groups of Trichoderma. III. Hyphal interaction. Transactions of the British Mycological Society 57: 363-369.

Ezra D \& Strobel GA (2003) Effect of substrate on the bioactivity of volatile antimicrobials produced by Muscodor albus. Plant Science 165: 1229-1238.

FAO - Food and Agriculture Organization of the United Nations (2014). Available from: <http://www.faostat. fao.org/site/339/default.aspx>. Acesssed: 9 out. 2016.

Feichtenberger E (2001) Doenças incitadas por Phytophthora em citros. In: Luz EDMN, Matsuoka K, Santos AF \& Bezerra JL (Eds). Doenças causadas por Phytophthora no Brasil. São Paulo: Livraria Rural, p. 283-342.

Fialho MB, Toffano L, Pedroso MP, Augusto F \& Pascholati SF (2010) Volatile organic compounds produced by Saccharomyces cerevisiae inhibit the in vitro development of Guignardia citricarpa, the causal agent of citrus black spot. World Journal of Microbiology \& Biotechnology 26: 925-932.

Frighetto RTS \& Melo IS (1995) Produção de antibióticos por microrganismos. In: Melo IS \& Sanhuez RMV. (Coords). Métodos de seleção de microrganismos antagônicos a fitopatógenos. Jaguariúna: Embrapa Meio Ambiente, p. 40-46.

Graham JH \& Menge JA (1999) Root diseases. In: Timmer LW \& Duncan LW. Citrus health management. Saint Paul: APS Press, p. 126-135.

Graham JH \& Timmer LW (1992) Phytophthora disease of citrus. In: Kummer J (Ed). Plant diseases of international importance. New Jersey: Prentice Hall, p. 250-269.

Harman GE, Howell CR, Viterbo A, Chet I \& Lorito M (2004) Trichoderma species opportunistic, avirulent plant symbionts. Nature Reviews Microbiology 2: 43-56.

Howell CR (2003) Mechanisms employed by Trichoderma species in the biological control of plant diseases: The history and evolution of current concepts. Plant Disease 87: 4-10.

Isaias CO, Martins I, Silva JBT, Silva JT \& Mello SCM (2014) Ação antagônica e de metabolitos bioativos de Trichodema spp. contra os patógenos Sclerotium rolfsii e Verticillium dahlia. Summa Phytopathologica 40: 34-41.

Kupper KC \& Fernandes NG (2002) Isolamento e seleção de Bacillus spp. para o controle de Colletotrichum acutatum em flores destacadas de lima ácida 'Tahiti'. Summa Phytopathologica 28: 292-295.

Leoni C \& Ghini R (2002) Efeito do lodo de esgoto na indução de supressividade in vitro a Phytophthora nicotianae. Fitopatologia Brasileira 28: 67-75.

Malajczuk N (1983) Microbial antagonism to Phytophthora. In: Erwin DC, Bartnicki GS \& Tsao PH. (Eds). Phytophthora: its biology, taxonomy, ecology and pathology. Saint Paul: APS Press, p. 197-218.

Martins-Corder MP \& Melo IS (1998) Antagonismo in vitro de Trichoderma spp. a Verticillium dahliae kleb. Scientia Agrícola 55: 1-7.

Matheron ME \& Porchas M (2000) Impacto of azoxystrobin, dimethomorph, fluazinam, fosetyl-al, and metalaxyl on growth, sporulation, and zoospore cyst germination of three Phytophthora spp. Plant Disease 84: 454-458.

Monte E (2001) Understanding Trichoderma: between biotechnology and microbial ecology. International Microbiology 4: 1-4.

Rossi-Rodrigues BC, Brochetto-Braga MR, Tauk-Tornisielo SM, Carmona EC, Arruda VM \& Chaud Netto J (2009) Comparative grown of Trichoderma strains in different nutritional sources, using bioscreen automated system. Brazilian Journal of Microbiology 40: 404-410. 
Saba H, Vibhash D, Manisha M, Prashant KS, Farhan H \& Tauseef A (2012) Trichoderma - a promising plant growth stimulator and biocontrol agent. Mycosphere 3: 524-531.

Saksirirat W, Chareerak P \& Bunyatrachata W (2009) Induced systemic resistance of biocontrol fungus, Trichoderma spp. against bacterial and gray leaf spot in tomatoes. Asian Journal of Food and Agro-Industry S99-S104. Special Issue.
Woo SL, Ruocco M, Vinale F, Nigro M, Marra R, Lombardi N, Pascale A, Lanzuise S, Manganiello G \& Lorito M (2014) Trichoderma-based products and their widespread use in agriculture. The Open Mycology Journal 8: 71-1.

Received: May 03, 2016

Accepted: Jan. 04, 2017 